\title{
The Correlation of Clinicopathological Findings and Neutrophil-to- Lymphocyte and Platelet-to-Lymphocyte Ratios in Papillary Thyroid Carcinoma
}

\author{
Papiller Tiroid Kanserli Hastalarda Nötrofil/Lenfosit ve Trombosit/Lenfosit Oranlarının Kliniko- \\ Patolojik Bulgularla Ilişkisi
}

\section{(1) Yeşim Ceylan1, (1) Kamil Kumanlıŏglu2, (1) Aylin Oral2, (1) Yeşim Ertan³, (1) Zehra Özcan²}

IAdıyaman Faculty of Medicine Training and Research Hospital, Department of Nuclear Medicine, Adıyaman, Turkey

2Ege University Faculty of Medicine, Department of Nuclear Medicine, Izmir, Turkey

${ }^{3}$ Ege University Faculty of Medicine, Department of Pathology, Izmir, Turkey

\begin{abstract}
Objectives: Inflammatory markers such as neutrophil-to-lymphocyte ratio (NLR) and platelet-to-lymphocyte ratio (PLR) have been recently introduced as potential biomarkers for tumor pathogenesis, development and prognosis in solid tumors. Our aim was to assess the correlation of clinicopathological features and NLR and PLR in patients with papillary thyroid carcinoma (PTC).

Methods: A total of 201 papillary thyroid carcinoma patients were divided into groups with a cut-off preoperative median NLR and PLR value of 1,92 and 123.9, respectively. The correlation of NLR and PLR and clinicopathological features including age, tumor size, extra-thyroidal extension, thyroid capsule invasion, surgical margin positivity, multifocality, bilaterality of the patients were analyzed.

Results: The mean NLR and PLR were $2.11 \pm 0.94,129.69 \pm 42.81$, respectively. Larger tumor size and higher positivity of extra-thyroidal spread were correlated with higher NLR values. No significant relationship was found between NLR and age, presence of thyroid capsule invasion, surgical margin positivity, multifocality, bilaterality, and lymph node metastasis. Also no significant association was observed between the clinicopathological features and PLR.

Conclusion: High NLR was found to correlate with tumor size and extra-thyroidal extension. NLR may be used as a marker to determine the clinical behavior of disease in patients with papillary thyroid carcinoma (PTC).

Keywords: Neutrophil-to-lymphocyte ratio, platelet-to-lymphocyte ratio, papillary thyroid carcinoma
\end{abstract}

\section{Öz}

Amaç: Son yıllarda nötrofil/lenfosit oranı (NLO) ve trombosit/lenfosit oranı (TLO) gibi enflamatuvar belirteçlerin solid tümör patogenezinde, gelişmesinde ve prognozunda etkili olduğuna dair çalışmalar mevcuttur. Bu çalışmada tiroid papiller kanserinin (PTK) kliniko-patolojik özellikleri ile NLO ve TLO arasındaki ilişkinin retrospektif olarak incelenmesi amaçlanmıştır.

Yöntem: Çalışmaya dahil edilen 201 hasta preoperatif medyan NLO (grup $1<1,92$ ve grup $2 \geq 1$,92) ve medyan TLO (grup $1<123,9$ ve grup $2 \geq 123,9)$ değerlerine göre gruplara ayrıldı. NLO ve TLO ile hastaların yaş, tümör boyutu, ekstra-tiroidal yaylım, tiroid kapsül invazyonu, cerrahi sınır pozitifliği, multifokalite, bilateralite gibi kliniko-patolojik özellikleri arasındaki ilişki değerlendirildi.

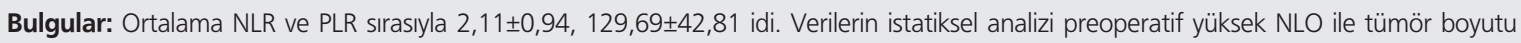
$(p=0,002)$ ve ekstra-tiroidal yayılım ( $p=0,028)$ arasında anlamlı ilişki bulunduğunu gösterdi. Yaş, tiroid kapsül invazyonu, cerrahi sınır pozitifliği,

Address for Correspondence: Yeşim Ceylan MD, Adıyaman Faculty of Medicine Training and Research Hospital, Department of Nuclear Medicine, Adıyaman, Turkey Phone: +90 5077071889 E-mail: dryesimceylan@gmail.com ORCID ID: orcid.org/0000-0002-9677-5307

Received: 08.08.2018 Accepted: 19.12.2018

${ }^{\circ}$ Copyright 2019 by Turkish Society of Nuclear Medicine

Molecular Imaging and Radionuclide Therapy published by Galenos Yayınevi. 
multifokalite, bilateralite ile NLO arasında ise ilişki saptanmadı ( $p>0,05)$. TLO ile kliniko-patolojik özellikler arasında anlamlı istatistiksel ilişki gösterilemedi $(p>0,05)$.

Sonuç: Çalışmamız PTK de NLO ile tümör boyutu ve ekstra-tiroidal yaylım arasında istatistiksel olarak anlamlı ilişki bulunduğunu göstermektedir. NLO'nun diğer bazı solid tümörlerde olduğu gibi PTK olgularında hastalığın klinik davranışını belirlemek için yararlı bir belirteç olarak kullanılabileceği düşünülmektedir.

Anahtar kelimeler: Nötrofil/lenfosit oranı, trombosit/lenfosit oranı, papiller tiroid kanseri

\section{Introduction}

It has been demonstrated that inflammation might play an important role in cancer development and progression (1). The interaction between cancer and inflammation is assumed to be complicated and based on different physiological processes such as miscellaneous inflammatory cells, mediators and signaling pathways in cancer tissue (2). It has been indicated that cancer-related inflammatory response leads to proliferation and survival of tumor cells, angiogenesis and finally to cancer progression by affecting tumor microenvironment in numerous tumors (3). The increase of pro-inflammatory cytokine is regarded to be indicative of disease prognosis and patient response to the tumor. Thus, systemic inflammatory markers including C-reactive protein (CRP), albumin concentration, neutrophilto-lymphocyte ratio (NLR), platelet-to-lymphocyte ratio (PLR) may have potential roles as prognostic biomarkers (4).

$N L R$, which is simply measured by a routine peripheral blood test, has been widely used as an indicator of general immunoreactivity. It has been studied in various tumors and found to be useful as a prognostic indicator, estimating overall and recurrence free survival in some solid tumors such as esophagus, stomach, pancreas, colon, ovary, kidney, lung and prostate cancers $(5,6,7)$. However, studies examining the role of NLR in thyroid cancer with an increasing frequency worldwide are limited. In the current study, we aimed to evaluate the correlation of clinicopathological features and inflammatory indicators in papillary thyroid cancer.

\section{Materials and Methods}

\section{Patients}

The study group included papillary thyroid carcinoma patients referred to Department of Nuclear Medicine between January 2015 and December 2016. Those patients with confirmed diagnosis of thyroid papillary carcinoma greater than $1 \mathrm{~cm}$ on a detailed histopathological examination and total blood count analysis just prior to thyroid surgery (within a 2 days interval) were selected. Patients with coexisting hematologic diseases, additional tumors, acute myocardial infarction or coronary revascularization in the last 6 months, acute infectious diseases, chronic drug (steroids etc.) use that could affect blood analysis, presence of lymphocytic infiltration suggesting thyroiditis on histopathology and abnormal white blood cells (WBC) measurements were excluded from the study. The medical records of all patients were examined and those without symptoms of acute infections and normal blood cells were included. The final study population included a total of 201 patients. Demographic characteristics of the patients (age, gender), clinical records including histopathologic findings, and pre-operative complete blood count results were obtained. All surgical specimens were examined in detail for certain pathologic features including tumor size, presence of thyroid capsule invasion, extra-thyroidal extension, surgical margin positivity, bilateral involvement, presence of multifocal tumor and lymph node metastasis. We used complementary data achieved by ultrasound and post ablation whole body iodine scan to assess lymph node involvement as neck dissection was not routinely performed to all patients. Complete blood count analyzes; hemoglobin level, WBC, neutrophil and lymphocyte counts were obtained by using a Dyn Ruby Cell (ABBOTT, USA) hematology analyzer. The NLR was calculated by dividing the absolute neutrophil count by the absolute lymphocyte count; similarly, the PLR was calculated by dividing the absolute platelet count by the absolute lymphocyte count. We formed 2 cohort groups according to the values above and below the median value of NLR and PLR. These groups were compared in terms of the aforementioned clinicopathologic characteristics.

The study was approved by the Ege University of Local Ethics Committee (protocol number: 17-12.1/33).

\section{Statistical Analysis}

Statistical Package for Social Sciences version 15.0 (SPSS Inc., Chicago, IL, USA) was used for statistical analysis. Kolmogorov-Smirnov test was used to determine if sample data is normally distributed. The Mann-Whitney $U$ test was then used to compare the continuous variables which did not show normal distribution. The correlation between the nominal variables was compared with the chi-square test. P 
value less than 0.05 was considered statistically significant.

\section{Results}

An overview of patient characteristics is shown in Table 1. The mean age of the study population was $47.1 \pm 14.3$ years, and the female/male ratio was 155/46. Two of the patients had distant metastatic involvement (lung) and 57 had cervical lymph node metastases.

The mean NLR and PLR were $2.11 \pm 0.94$ and $129.69 \pm 42.81$, respectively. The patients were divided into two groups according to the median NLR as those below (group 1) and above (group 2) 1.92. When clinic-pathologic features were compared by using chi-square and Mann-Whitney $U$ tests, larger tumor size (group 1: $2.24 \pm 1.14 \mathrm{~cm}$; group 2: $2.79 \pm 1.49 \mathrm{~cm}, p=0.002)$, and higher positivity of extrathyroidal spread (group 1: 3 patients, group 2: 11 patients, $p=0.028$ ) were found to be statistically related with the higher values of NLR in group 2. Statistical analyses did not reveal a significant correlation between NLR and age $(<45$ years, $\geq 45$ years), presence of thyroid capsule invasion, surgical border positivity, multifocality, bilaterality, lymph node metastasis (Table 2 ). When the cohort was also divided into two groups according to median PLR (PLR $<123,9$ and PLR 2123,9 ), no statistically significant correlation was detected with clinic-pathologic features (Table 3).

\section{Discussion}

It has been widely recognized that inflammation and cancer are closely related to each other as inflammation has both cancer-inhibiting and neoplasia modelling properties $(8,9,10)$. The inflammatory effect on tumor pathogenesis, which was first described by Rudolf Virchow, has been recognized as an important concept also for the development and proliferation of the tumor by reducing

Table 1. Demographic characteristics and hematological data of papillary thyroid carcinoma patients

\begin{tabular}{|c|c|c|}
\hline & Mean \pm SD & Minimum - Maximum \\
\hline Age (years) & $47.10 \pm 14.32$ & $19-83$ \\
\hline \multicolumn{3}{|l|}{ Sex } \\
\hline Female (n, \%) & $155(77.1 \%)$ & \\
\hline Male $(n, \%)$ & $46(22.9 \%)$ & \\
\hline Neutrophils & $4.40 \pm 1.32$ & $1.95-8.88$ \\
\hline Lymphocytes & $2.23 \pm 0.65$ & $0.87-4.68$ \\
\hline Platelets & $271.28 \pm 64.35$ & $138.00-466.00$ \\
\hline NLR & $2.11 \pm 0.94$ & $0.78-8.28$ \\
\hline PLR & $129.69 \pm 42.81$ & $56.11-311.49$ \\
\hline
\end{tabular}

SD: Standard deviation, NLR: Neutrophil-to-lymphocyte ratio, PLR: Platelet-tolymphocyte response to anticancer agents $(11,12)$. In recent studies, there is growing evidence on the effect of inflammation on cancer pathogenesis, progression and response to treatment $(2,12)$. Inflammation, cytokines and chemokines induce tumor proliferation, angiogenesis and metastasis by CRP and neutrophil induction. In addition, it is considered to play an important role in the development and proliferation of the tumor by reducing the response to anticancer agents (2). The physiologic response of leukocytes to stress results in an increase in the number of neutrophils and a decrease in the number of lymphocytes (13). The inflammatory cytokines, leukocytes and phagocytic mediators that cause neutrophil release, lead to DNA damage. It inhibits

Table 2. Association of preoperative neutrophil-tolymphocyte ratio with clinicopathological characteristics of papillary thyroid carcinoma

\begin{tabular}{|c|c|c|c|c|}
\hline & Total & NLR $<1.92$ & $N L R \geq 1.92$ & p \\
\hline Total & $201(100 \%)$ & $100(49.8 \%)$ & $101(50.2 \%)$ & \\
\hline \multicolumn{5}{|l|}{ Age } \\
\hline$<45$ years & $81(40.3 \%)$ & $40(49.4 \%)$ & $41(50.6 \%)$ & \multirow{2}{*}{0.932} \\
\hline$\geq 45$ years & $120(59.7 \%)$ & $60(50.0 \%)$ & $60(50.0 \%)$ & \\
\hline \multicolumn{5}{|l|}{ Sex } \\
\hline Female & $155(77.1 \%)$ & $76(49.0 \%)$ & $79(51.0 \%)$ & \multirow{2}{*}{0.708} \\
\hline Male & $46(22.9 \%)$ & $24(52.2 \%)$ & $22(47.8 \%)$ & \\
\hline $\begin{array}{l}\text { Tumor } \\
\text { size }(\mathrm{cm})\end{array}$ & $2.51 \pm 1.35$ & $2.24 \pm 1.13$ & $2.79 \pm 1.48$ & $0.002 *$ \\
\hline \multicolumn{5}{|c|}{ Capsule invasion } \\
\hline Yes & $75(37.3 \%)$ & 37 (49.3\%) & $38(50.7 \%)$ & \multirow{2}{*}{0.927} \\
\hline No & $126(62.7 \%)$ & $63(50.0 \%)$ & $63(50.0 \%)$ & \\
\hline \multicolumn{5}{|c|}{ Multifocality } \\
\hline Yes & $80(39.8 \%)$ & $41(51.3 \%)$ & $39(48.8 \%)$ & \multirow{2}{*}{0.730} \\
\hline No & $121(60.2 \%)$ & $59(48.8 \%)$ & $62(51.2 \%)$ & \\
\hline \multicolumn{5}{|c|}{ Bilaterality } \\
\hline Yes & $60(100 \%)$ & $32(53.3 \%)$ & $28(46.7 \%)$ & \multirow{2}{*}{0.508} \\
\hline No & $141(100 \%)$ & $68(48.2 \%)$ & $73(51.8 \%)$ & \\
\hline \multicolumn{5}{|c|}{ Surgical margin positivity } \\
\hline Yes & $19(9.5 \%)$ & $10(52.6 \%)$ & $9(47.4 \%)$ & \multirow{2}{*}{0.792} \\
\hline No & $182(90 \%)$ & $90(49.5 \%)$ & $92(50.5 \%)$ & \\
\hline \multicolumn{5}{|c|}{ Extra-thyroidal spread } \\
\hline Yes & $14(7.0 \%)$ & $3(21.4 \%)$ & $11(78.6 \%)$ & \multirow{2}{*}{0.028 * } \\
\hline No & $187(93.0 \%)$ & 97 (51.9\%) & $90(48.1 \%)$ & \\
\hline \multicolumn{5}{|c|}{ Lymph node metastasis } \\
\hline Yes & 57 (28.4\%) & $26(45.6 \%)$ & $31(54.4 \%)$ & \multirow{2}{*}{0.460} \\
\hline No & $144(71.6 \%)$ & $74(51.4 \%)$ & $70(48.6 \%)$ & \\
\hline
\end{tabular}

NLR: Neutrophil-to-lymphocyte ratio, ${ }^{*} \mathrm{p}<0.05$ 
apoptosis and induces tumor angiogenesis resulting in tumor growth, progression, and metastasis. On the other hand, lymphocytes also play a major role in the prevention of tumor growth and immunity (10).

Recently some studies pointed out that elevated blood NLR that can be easily calculated from blood tests might be used to predict some aggressive features in a variety of cancers $(5,6,7)$. In the current study, we aimed to examine the value of NLR and PLR in papillary thyroid cancers in which the current relevant literature is quite limited $(14,15,16)$.

In the current study patients with papillary thyroid carcinoma, we have noted a statistically significant association between high preoperative NLR value and size and extra-thyroidal extension of the tumor. This observation was in agreement with the study of Manatakis et al. (8) indicating that the high levels of NLR was associated with extra-thyroidal invasion. Also, Liu et al. (16) showed the correlation of high preoperative NLR values with increased tumor size and recurrence risk in differentiated thyroid cancers. Several additional studies have also supported the correlation of tumor size and increasing $\operatorname{NLR}(14,15,16)$. However, in our study, pathologic findings other than tumor size and extra-thyroidal extension did not appear to be inter-related. Moreover, no correlation was found between PLR and clinic-pathologic features of thyroid tumors. This inconsistent observation might be related to several factors related to the study population and methodology. Moreover, as inflammation is a slow process and most of the study patients herein represent early stage of the disease, no significant correlation between inflammation

Table 3. Association of preoperative platelet-to-lymphocyte with clinicopathological characteristics of papillary thyroid carcinoma

\begin{tabular}{|c|c|c|c|c|}
\hline & Total & PLR $<123.9$ & PLR $\geq 123.9$ & $\mathbf{p}$ \\
\hline Total & $201(100 \%)$ & $100(49.8 \%)$ & $101(50.2 \%)$ & \\
\hline \multicolumn{5}{|l|}{ Age } \\
\hline$<45$ years & $81(40.3 \%)$ & $44(54.3 \%)$ & $37(45.7 \%)$ & \multirow{2}{*}{0.287} \\
\hline$\geq 45$ years & $120(59.7 \%)$ & $56(46.7 \%)$ & $64(53.3 \%)$ & \\
\hline \multicolumn{5}{|l|}{ Sex } \\
\hline Female & $155(77.1 \%)$ & $72(46.5 \%)$ & $83(53.5 \%)$ & \multirow{2}{*}{0.086} \\
\hline Male & $46(22.9 \%)$ & $28(60.9 \%)$ & $18(39.1 \%)$ & \\
\hline Tumor size $(\mathrm{cm})$ & $2.51 \pm 1.35$ & $2.46 \pm 1.36$ & $2.56 \pm 1.33$ & 0.309 \\
\hline \multicolumn{5}{|l|}{ Capsule invasion } \\
\hline Yes & $75(37.3 \%)$ & $34(45.3 \%)$ & $41(54.7 \%)$ & \multirow{2}{*}{0.334} \\
\hline No & $126(62.7 \%)$ & $66(52.4 \%)$ & $60(47.6 \%)$ & \\
\hline \multicolumn{5}{|l|}{ Multifocality } \\
\hline Yes & $80(39.8 \%)$ & $44(55.0 \%)$ & $36(45.0 \%)$ & \multirow{2}{*}{0.226} \\
\hline No & $121(60.2 \%)$ & $56(46.3 \%)$ & $65(53.7 \%)$ & \\
\hline \multicolumn{5}{|l|}{ Bilaterality } \\
\hline Yes & $60(100 \%)$ & $35(58.3 \%)$ & $25(41.7 \%)$ & \multirow{2}{*}{0.112} \\
\hline No & $141(100 \%)$ & $65(46.1 \%)$ & $76(53.9 \%)$ & \\
\hline \multicolumn{5}{|c|}{ Surgical margin positivity } \\
\hline Yes & $19(9.5 \%)$ & $9(47.4 \%)$ & $10(52.6 \%)$ & \multirow{2}{*}{0.827} \\
\hline No & $182(90 \%)$ & $91(50.0 \%)$ & $91(50.0 \%)$ & \\
\hline \multicolumn{5}{|c|}{ Extra-thyroidal spread } \\
\hline Yes & $14(7.0 \%)$ & $8(57.1 \%)$ & $6(42.9 \%)$ & \multirow{2}{*}{0.566} \\
\hline No & $187(93.0 \%)$ & $92(49.2 \%)$ & 95 (50.8\%) & \\
\hline \multicolumn{5}{|c|}{ Lymph node metastasis } \\
\hline Yes & $57(28.4 \%)$ & $32(56.1 \%)$ & $25(43.9 \%)$ & \multirow{2}{*}{0.254} \\
\hline No & $144(71.6 \%)$ & $68(47.2 \%)$ & $76(52.8 \%)$ & \\
\hline
\end{tabular}


and NLR was noted. In the study of Manatakis et al. (8), the study group (205 patients) included those cases with tumors smaller than $1 \mathrm{~cm}$ and those with co-existing thyroiditis. Actually this is divergent from our cases as we have excluded smaller tumors and those with thyroiditis. In the study of Gong et al. (14), the median NLR used as a cut-off value was 2.0 that is similar to our study. They have found a positive correlation between high NLR and lymph node metastasis, multifocality and tumor size. However it should be noted that these NLR values obtained in the studies focusing on thyroid carcinoma are lower than those in previous studies focusing on solid tumors. As an example, Templeton et al. (17) found the median NLR value as 4 in a meta-analysis with solid tumors. Moreover, it should also be considered that there has been no clear validation of the cut-off values used in the literature (14). Regarding the correlation between disease extension and NLR, Manatakis et al. (8) and Gong et al. (14) found an association between the presence of lymph node metastases, which is not supported in our series. As stated above, this might be linked to the differences in the study population and the number of patients with lymph node involvement in their series which is obviously smaller than ours. On contrary to this, Kim et al. (15) have indicated lack of evidence for the association between NLR and the clinicopathological findings of the tumor based on 1066 female patients. However, they have found a significant correlation between high pre-operative PLR and lymph node metastasis. In the current study, while a significant correlation between NLR and tumor size and extra-thyroidal extension was noted, an association with PLR was not detected. In most of the previous studies, both NLR and PLR were found to be valuable in several solid tumors $(18,19,20,21)$. Costantini et al. (22) suggested that production of bone marrowstimulating cytokines as a result of inflammatory response to malignancy may play an important role in the regulation of platelet counts in neoplasms (23). Platelets can give rise to angiogenesis and extra-vasation of tumor cells by releasing vascular endothelial growth factor (VEGF) (24). VEGF and various growth factors have been suggested to induce angiogenesis and vascularization resulting in the increase of tumor growth rates (25). Some proinflammatory cytokines, such as IL-1 and IL-6, also cause megakaryocyte proliferation resulting in thrombocytosis $(24,25)$.

Several clinical studies showed that high PLR correlates with worse clinicopathological features in patients with HCC $(26,27)$. Deng et al. $(28)$ performed a literature search in PubMed, Web of Science and Embase. This meta-analysis included 13 studies involving 4.621 patients. The result indicated that the elevated PLR level was associated with lymph node metastasis, higher tumor stage, deeper tumor invasion and longer tumor length, indicating that the level of PLR is important for predicting clinicopathological features. Most of the studies have been performed in esophagus, ovary, breast, prostate, stomach, colorectal and hepatocellular carcinomas with limited studies focusing on thyroid cancer $(29,30)$. Previously Kim et al. (15) documented elevated PLR in association with increased risk of lateral lymph node involvement. However, when combining NLR and PLR, they were not able to support the correlation of these markers with prognostic factors in papillary thyroid carcinoma. A high preoperative PLR is associated with poor prognosis in operable colorectal and pancreatic cancers (19), and a high preoperative NLR is poor prognostic marker in some cancers, including gastric, pancreatic, colorectal, cholangiocarcinoma, lung and ovarian cancers (6). But only a few studies have evaluated the significance of the NLR and also PLR in thyroid cancer. Measurement of the PLR and NLR were cost-effective, safe, and readily available so we evaluated the association between preoperative NLR and PLR and the clinicopathological characteristics of patients with PTC. Unfortunately; it should be considered that this study has some limitations related to the limited number of patients and retrospective study design. Also, NLR and PLR values are not specific for inflammation process and may be affected by many factors. Moreover, lack of standard cut-off values for NLR and PLR also appear to be important to validate these observations. Another limitation is that patients who had PTC below $1 \mathrm{~cm}$ have not been investigated in this study although tumors below $1 \mathrm{~cm}$ may have metastasis or extra-thyroidal invasion. Further studies including thyroid papillary microcarcinomas may provide future guidance.

\section{Conclusion}

In the current analysis, we identified a statistically significant correlation between NLR and tumor size and extra-thyroidal extension. However, no evidence of correlation with these features and PLR was observed. The current results indicate $N L R$, which is a quite simple and inexpensive test, as a potential marker to determine clinical behavior in papillary thyroid carcinoma patients.

\section{Ethics}

Ethics Committee Approval: The study was approved by the Ege University of Local Ethics Committee (protocol number: 17-12.1/33).

Informed Consent: Retrospective study.

Peer-review: Externally and internally peer-reviewed.

\section{Authorship Contributions}

Surgical and Medical Practices: Y.C., Z.Ö., Y.E., A.O., 
Concept: Y.C., Z.Ö., Design: Y.C., Z.Ö., Data Collection or Processing: Y.C., Analysis or Interpretation: Y.C., Z.Ö., K.K., Literature Search: Y.C., Z.Ö., Writing: Y.C., Z.Ö.

Conflict of Interest: No conflict of interest was declared by the authors.

Financial Disclosure: The authors declared that this study received no financial support.

\section{References}

1. Whiteside $\mathrm{TL}$. The tumor microenvironment and its role in promoting tumor growth. Oncogene 2008;27:5904-5912.

2. Mantovani A, Allavena P, Sica A, Balkwill F. Cancer related inflammation. Nature 2008;454:436-444.

3. Li X, Ma X, Tang L, Wang B, Chen L, Zhang F, Zhang X. Prognostic value of neutrophil-to-lymphocyte ratio in urothelial carcinoma of the upper urinary tract and bladder: a systematic review and metaanalysis. Oncotarget 2017;8:62681-62692.

4. de Visser KE, Coussens LM. The inflammatory tumor microenvironment and its impact on cancer development. Contrib Microbiol 2006;13:118-137.

5. Moore MM, Chua W, Charles KA, Clarke SJ, Inflammation and cancer: causes and consequences. Clin Pharmacol Ther 2010;87;504-508.

6. Liu CL, Lee JJ, Liu TP, Chang YC, Hsu YC, Cheng SP. Blood neutrophilto-lymphocyte ratio correlates with tumor size in patients with differentiated thyroid cancer. J Surg Oncol 2013;107:493-497.

7. Hsueh C, Tao L, Zhang M, Cao W, Gong H, Zhou J, Zhou L. The prognostic value of preoperative neutrophils, platelets, lymphocytes, monocytes and calculated ratios in patients with laryngeal squamous cell cancer. Oncotarget 2017;8:60514-60527.

8. Manatakis DK, Tseleni-Balafouta S, Balalis D, Soulou VN, Korkolis DP, Sakorafas GH, Plataniotis G, Gontikakis E. Association of Baseline Neutrophil-to-Lymphocyte Ratio with Clinicopathological Characteristics of Papillary Thyroid Carcinoma. Int J Endocrinol 2017;2017:8471235.

9. Tong YS, Tan J, Zhou XL, Song YQ, Song YJ. Systemic immuneinflammation index predicting chemoradiation resistance and poor outcome in patients with stage III non-small cell lung cancer. J Transl Med 2017:15:221.

10. Dunn GP, Old LJ, Schreiber RD. The Immunobiology of Cancer Immunosurveillance and Immunoediting. Immunity 2004;21:137148.

11. Mantovani A, Allavena $P$, Sica A, Balkwill F. Cancer-related inflammation. Nature 2008;454:436-444.

12. Colotta F, Allavena P, Sica A, Garlanda C, Mantovani A. Cancerrelated inflammation, the seventh hallmark of cancer: links to genetic instability. Carcinogenesis 2009;30:1073-1081.

13. Jilma B, Blann A, Pernerstorfer T, Stohlawetz P, Eichler HG, Vondrovec B, Amiral J, Richter $V$, Wagner OF. Regulation of adhesion molecules during human endotoxemia. No acute effects of aspirin. Am J Respir Crit Care Med 1999;159:857-863

14. Gong W, Yang S, Yang X, Guo F. Blood preoperative neutrophilto-lymphocyte ratio is correlated with TNM stage in patients with papillary thyroid cancer. Clinics (Sao Paulo) 2016;71:311-314.

15. Kim SM, Kim EH, Kim BH, Kim JH, Park SB, Nam YJ, Ahn KH, Oh MY, Kim WJ, Jeon YK, Kim SS, Kim YK, Kim IJ. Association of the Preoperative Neutrophil-to-lymphocyte Count Ratio and Platelet-toLymphocyte Count Ratio with Clinicopathological Characteristics in Patients with Papillary Thyroid Cancer. Endocrinol Metab (Seoul) 2015;30:494-501.

16. Liu JF, Ba L, Lv H, Lv D, Du JT, Jing XM, Yang NJ, Wang SX, Li C, $\mathrm{Li} X X$. Association between neutrophil-to-lymphocyte ratio and differentiated thyroid cancer: a meta-analysis. Sci Rep 2016:6:38551.

17. Templeton AJ, Ace O, McNamara MG, Al-Mubarak M, Vera-Badillo FE, Hermanns T, Seruga B, Ocaña A, Tannock IF, Amir E. Prognostic Role of Platelet to Lymphocyte Ratio in Solid Tumors: A Systematic Review and Meta-Analysis. Cancer Epidemiol Biomarkers Prev 2014;23:1204-1212.

18. Roxburgh CS, McMillan DC. Role of systemic inflammatory response in predicting survival in patients with primary operable cancer. Future Oncol 2010;6:149-163.

19. Smith RA, Bosonnet $L$, Raraty $M$, Sutton $R$, Neoptolemos $J P_{\text {, }}$ Campbell F, Ghaneh P. Preoperative platelet-lymphocyte ratio is an independent significant prognostic marker in resected pancreatic ductal adenocarcinoma. Am J Surg 2009;197:466-472.

20. Sharma R, Hook J, Kumar M, Gabra H. Evaluation of an inflammationbased prognostic score in patients with advanced ovarian cancer. Eur J Cancer 2008:44:251-256.

21. Feng JF, Huang Y, Chen QX. Preoperative platelet lymphocyte ratio $(P L R)$ is superior to neutrophil lymphocyte ratio (NLR) as a predictive factor in patients with esophageal squamous cell carcinoma. World J Surg Oncol 2014;12:58.

22. Costantini V, Zacharski LR, Moritz TE, Edwards RL. The platelet count in carcinoma of the lung and colon. Thromb Haemost 1990;64:501505.

23. Gu D, Szallasi A. Thrombocytosis Portends Adverse Prognosis in Colorectal Cancer: A Meta-Analysis of 5,619 Patients in 16 Individual. Anticancer Res 2017:37:4717-4726.

24. Patruno R, Arpaia N, Gadaleta CD, Passantino L, Zizzo N, Misino A, Lucarelli NM, Catino A, Valerio P, Ribatti D, Ranieri G. VEGF concentration from plasma activated platelets rich correlates with microvascular density and grading in canine mast cell tumour spontaneous model. J Cell Mol Med 2008;13:555-561.

25. Peduzzi P, Concato J, Kemper E, Holford TR, Feinstem AR. A simulation study of the number of events per variable in logistic regression analysis. J Clin Epidemiol 1996;49:1373-1379.

26. Goh BK, Kam JH, Lee SY, Chan CY, Allen JC, Jeyaraj P, Cheow PC, Chow PK, Ooi LL, Chung AY. Significance of neutrophil-to-lymphocyte ratio, platelet-to-lymphocyte ratio and prognostic nutrition index as preoperative predictors of early mortality after liver resection for huge $(>/=10 \mathrm{~cm})$ hepatocellular carcinoma. J Surg Oncol 2016;113:621627

27. Song W, Wang K, Zhong FP, Fan YW, Peng L, Zou SB. Clinicopathological and prognostic significance of platelet-to-lymphocyte ratio in patients with hepatocellular carcinoma. Oncotarget 2016:7:81830-81838.

28. Deng J, Zhang P, Sun Y, Peng P, Huang Y. Prognostic and clinicopathological significance of platelet to lymphocyte ratio in esophageal cancer: a meta-analysis. J Thorac Dis 2018;10:15221531.

29. Jiang K, Lei J, Chen W, Gong Y, Luo H, Li Z, Gong R, Zhu J. Association of the preoperative neutrophil-to- lymphocyte and platelet-tolymphocyte ratios with lymph node metastasis and recurrence in patients with medullary thyroid carcinoma. Medicine (Baltimore) 2016:95:5079.

30. Kim JY, Park T, Jeong SH, Jeong CY, Ju YT, Lee YJ, Hong SC, Ha WS, Choi SK, Jung EJ. Prognostic importance of baseline neutrophil to lymphocyte ratio in patients with advanced papillary thyroid carcinomas. Endocrine 2014;46:526-531. 